\title{
Records on Otidea mirabilis and O. tuomikoskii from Finland
}

\author{
MATTEO CARBONE, EMANUELE CAMPO and JUKKA VAURAS
}

\begin{abstract}
CARBONE, M., CAMPO, E. \& VAURAS, J. 2010: Records on Otidea mirabilis and O. tuomikoskii from Finland. - Karstenia 50: 25-34. Helsinki. ISSN 0453-3402.

Otidea mirabilis and O. tuomikoskii are described from Finnish material deposited in the main herbaria of Finland. Colour photographs, microdrawings and the known Finnish distribution of both species are given. O. mirabilis, originally described from Italy, is a new record for the mycoflora of North Europe.
\end{abstract}

Key words: Ascomycetes, Finland, Otidea, Pezizales, taxonomy.

Matteo Carbone, Via Don Luigi Sturzo 173, I-16148 Genova, Italy; e-mail: matteocarb@hotmail.com

Emanuele Campo, Via dei Gelsi, 8, I-33077 Sacile(PN), Italy; e-mail: ecampo@alice.it Jukka Vauras, Biological Collections of Ảbo Akademi University, Herbarium, FI-20014 University of Turku, Finland; e-mail: jukvau@utu.fi

\section{Introduction}

Altogether 20 species of Otidea (Pers.) Bonord. were recently reported from Finland, including three taxa not yet validly published (Harmaja 2009). One more species is given in this paper. During excursions in northeastern Finland, Kuusamo, a beautiful Otidea was found. It was actually recognized as $O$. mirabilis Bolognini \& Jamoni in the field by the second author, who knew the species from Italy. The species was also recognized from specimens loaned from OULU.

During the revision of Otidea most collections deposited at the herbaria of Oulu University (OULU) and Turku University (TUR, TUR-A), several collections of $O$. tuomikoskii Harmaja were found. All available collections of that species from the herbarium of Helsinki University $(\mathrm{H})$ were also examined. This taxon was poorly known for a long time until Van Vooren et al. (2008) published a good description and colour photographs of it.

\section{Materials and methods}

Microscopic characters are based on dry specimens deposited in H, OULU and TUR. Two optical microscopes were used: Olympus CX41 trinocular and Ziel trinocular. The following reagents were used for mounts: Melzer's reagent, Cotton blue, Congo red. Water mounts were used for observation of the colours and also for spore size. At least 30 spores were measured from any apothecia. The revision of the collections was made mainly by the first author, and the microscopic drawings by the second author.

Otidea mirabilis Bolognini \& Jamoni

- Figs. 1, 3, 4

Otidea mirabilis Bolognini \& Jamoni, Funghi e Ambiente 85-86: 56. 2001.

Original diagnosis

Apothecia 2-3 cm alta, 2-3.5 cm lata, dense aggregata aut caespitosa, auriculiformis-erecta, uno latere usque ad basim incisa, subsessilia 


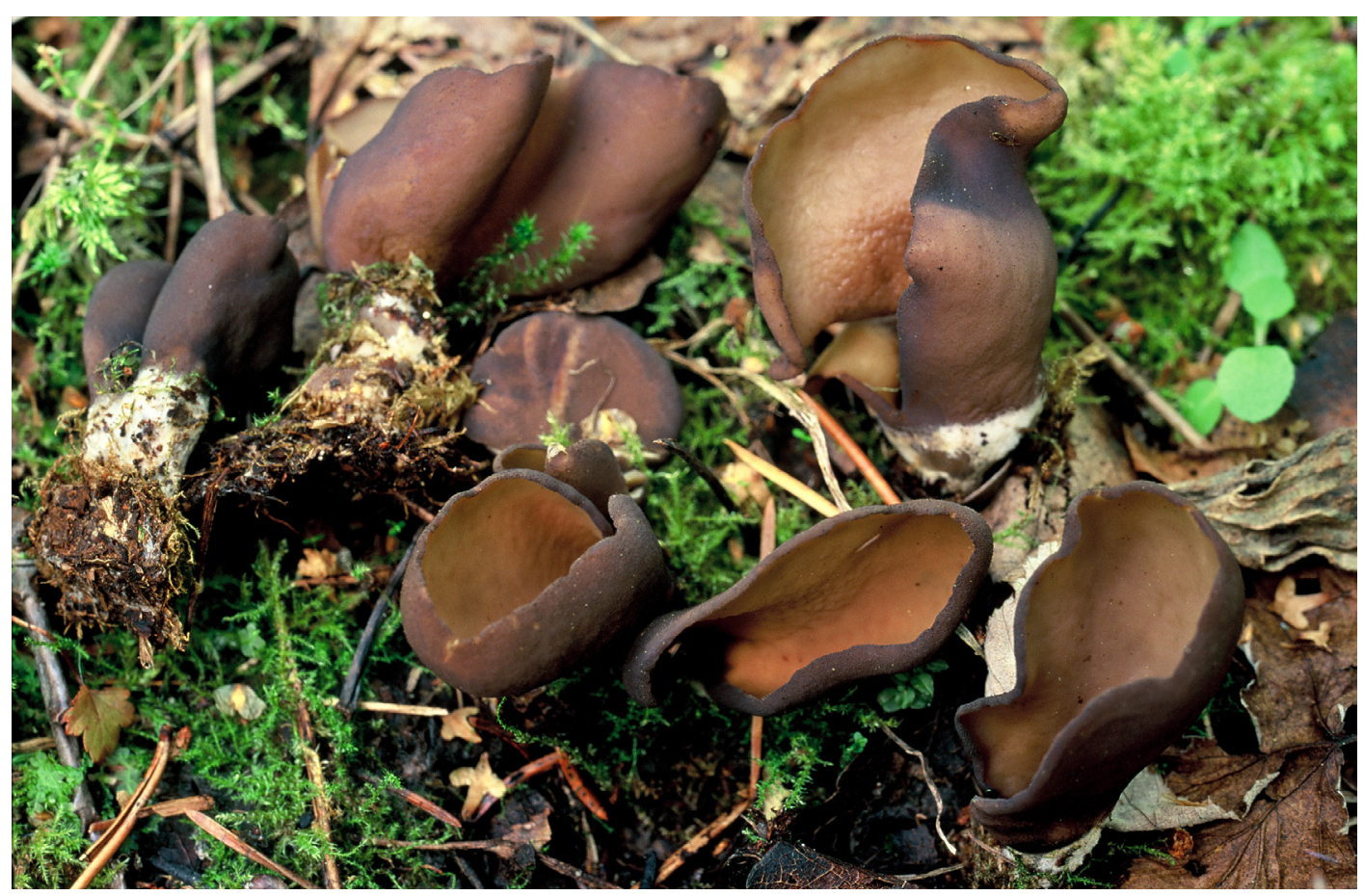

Fig. 1. Otidea mirabilis in situ. Finland, Koillismaa, Kuusamo, 2007 Campo \& Vauras 25090F. Photo J. Vauras

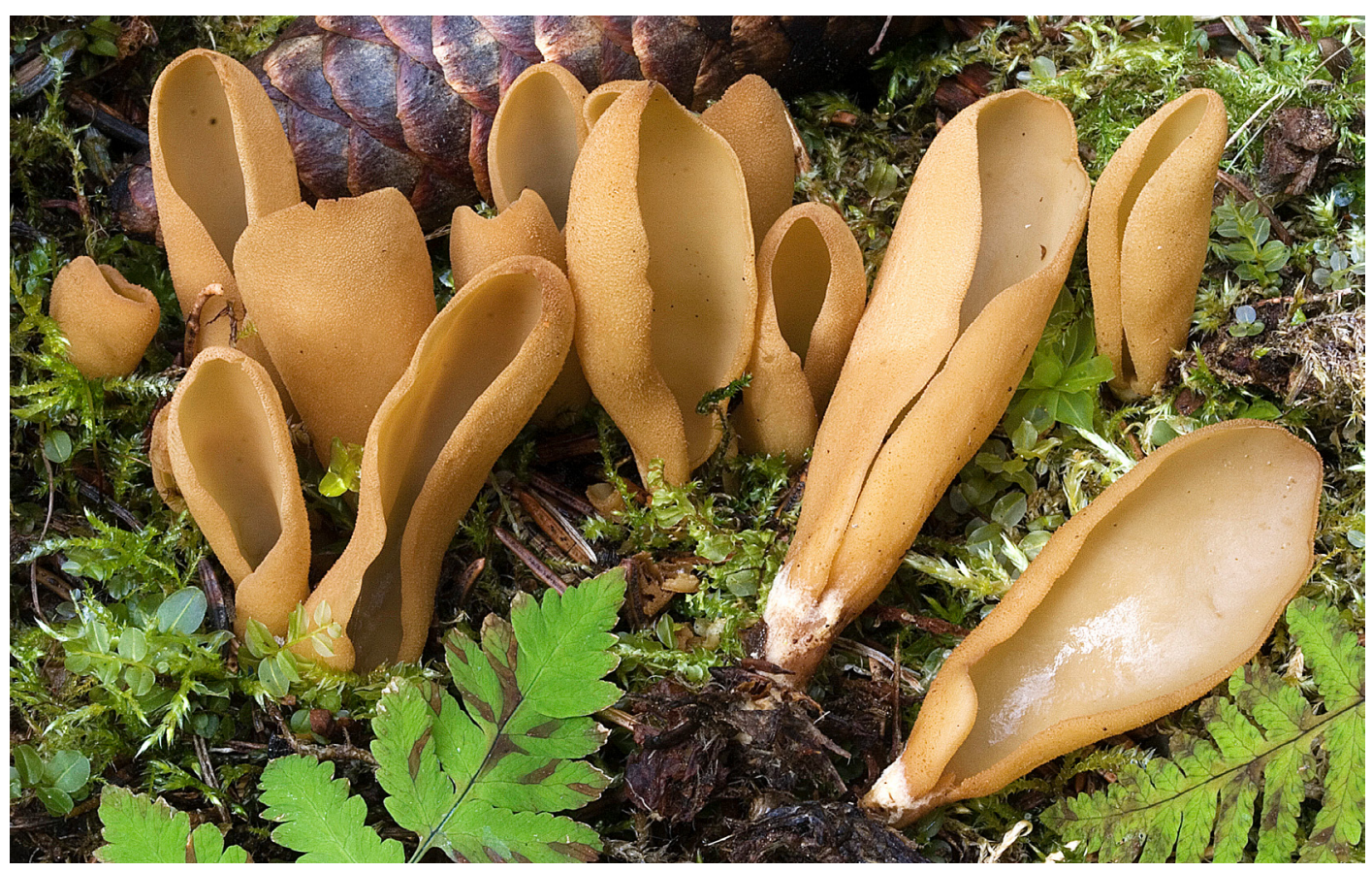

Fig. 2. Otidea tuomikoskii in situ. Finland, Koillismaa, Kuusamo, Carbone \& Vauras 26954F. Photo M. Carbone 
vel stipitata (stipite usque $5 \times 3 \mathrm{~mm}$ ). mycelium gossypinum, album vel roseum. Hymenium flavo-olivaceum, in sicco ocraceo-luteo maculato. Superficie externa furfuracea-granulosa, primo brunneo-violaceo-fusca dein coeruleo-violacea. Caro flavo-brunnea, $1 \mathrm{~mm}$ crassa. Subhymenium $100 \mu \mathrm{m}$ crassum, textura intricata. Excipulum medullare $-450 \mu \mathrm{m}$ crassum, textura intricata, cellulis hypharum oblongis-cylindraceis. Excipulum ectale -100 $4 \mathrm{~m}$ crassum, textura globuloso-angularis, catenis cellularum praedito (pilis externis incrustatis, globosis, claviformibus vel pyriformibus). Asci operculati, cylindracei, pedibus pleurorhynchis, apicem versus iodo non coerulescentes $(J-), 170-230(250) \times$ 9-11.5 (14) $\mu \mathrm{m}, 8$ sporas continentes. Ascosporae ellipsoideae, laeves, biguttulatae, 10-14.7 (15.5) × 6.4-7.2 (7.7) um. Paraphyses septate, subhyalinae, filiformes, 2-3 $\mu \mathrm{m}$ latae, apice curvatae et incrassatae ad 4(5) $\mu \mathrm{m}$. Habitat: ad humum silvaticum sub Picea et Larix. Holotypus in herbario GMFN sub n.1951, prope Alagna (Valle fluminis Sesia, VC) 1550 m s.l.m. lectus, 3.9.1999, legit D.B.

\section{Macroscopical features}

Fresh apothecia up to $60 \mathrm{~mm}$ long and up to 25 mm wide, slender, completely split on one side, with the apothecia margin inflexed for a long time. Stipe short (up to $10 \mathrm{~mm}$ ), covered by a whitish felt of mycelium. Hymenium smooth or weakly wrinkled, light ochraceous yellow to greenish grey. External surface finely granular, brown with deep bluish violet to greenish blue tint in young specimens, in age more brown to tawny. In dry state external surface fairly dark brown, base pale buff, hymenium fades to pale buff.

\section{Microscopic features}

Asci operculate, cylindrical, eight-spored, inamyloid, pleurorhynchous, 175-210 × 9.5-12.3 $\mu \mathrm{m}$. Spores uniseriate, elliptic-subfusoid to subnavicular, often slightly inequilateral, smooth, hyaline, with two large oil drops, (13-)13.5-15(-15.5) $\times$ 6-7(-7.5) $\mu \mathrm{m}, \mathrm{Q}=2.0-2.3$. Paraphyses cylindrical, 2-3 $\mu \mathrm{m}$ wide, branched below and septate; apex bent, widened up to 3.5-4 $\mu \mathrm{m}$, with small notches on the concave side, sometimes (sub) capitate. Subhymenium a textura intricata made up of hyphae 5-8 $\mu \mathrm{m}$ wide, with thickened, yellowish pigmented walls. Medullary excipulum a textura intricata, made up of hyphae 3-8 $\mu \mathrm{m}$ wide, septate, with thickened walls $0.5-1 \mu \mathrm{m}$, yellowish due to parietal pigment. Ectal excipulum a textura globuloso-angularis, $100-120 \mu \mathrm{m}$ thick, with elements $18-30 \times 12-15 \mu \mathrm{m}$. External layer made up of chains of globose to pearshaped cells, 13-25 $\mu \mathrm{m}$ wide, strongly incrusted by a brownish pigment.

Specimens examined: FINLAND. Varsinais-Suomi. Karjalohja, Karkalinniemi, Karkali Strict Nature Reserve, $\mathrm{S}$ of the central field. Spruce forest mixed with Betula etc., on ground rich in litter (needles) under spruce (in deep shadow), Grid 27 ${ }^{\circ}$ E 6685:3323, 14.IX.1978 Ulvinen (OULU). Pohjois-Karjala. Kitee, Nivunki, Nivunginsalo, yard of a house, on old, mossy heap with needles, wood and mull soil, Grid $27^{\circ}$ E 68866:36448, 12.IX.2009 Lahti (TUR). Koillismaa. Kuusamo, Oulanka National Park, Ampumavaara, E of Puukkosuo, S of the main road. Margin of eutrophic depression with Picea abies, Pinus sylvestris, Alnus incana, Betula and Salix, Grid $27^{\circ}$ E 73669:36036, 30.VIII.2007 Campo \& Vauras 25090F (TUR-A). ITALY. Piemonte. Vercelli, Alagna Valsesia, 3.IX.1999 Bolognini, (holotype, GMFN $1951=$ Herbarium of the mycological group G. Bresadola, Fara Novarese, Italy).

\section{Notes on ecology}

Two of the Finnish localities of Otidea mirabilis are in areas, which are known to have a rich biodiversity. Karkalinniemi belongs to Lohja district, were several new species of Otidea have been found (e.g. Harmaja 2009). The locality in Kuusamo is on a large slope of the valley of Oulankajoki river. This locality is rich mixed forest on calcareous ground, characterized by several rare plants and fungi. The site is fairly moist, and inundated in spring. Vascular plants at the site include Filipendula ulmaria, Geranium sylvaticum, Cirsium helenioides, Geum rivale, Rubus saxatilis, Ribes spicatum, Daphne mezereum, Elymus caninus, Parnassia palustris, Solidago virgaurea, Orthilia secunda, Goodyera repens, Cypripedium calceolus, Selaginella selaginoides, Gymnocarpium dryopteris and Cystopteris montana. Exacting species of fungi found nearby include Cortinarius dionysae Rob. Henry, C. odorifer Britzelm., Hebeloma syrjense P. Karst., Inocybe appendiculata Kühner, Lactarius scrobiculatus (Scop.: Fr.) Fr., Russula fulvograminea Ruots., Sarnari \& Vauras, R. olivina Ruots. \& Vauras, $R$. olivobrunnea Ruots. \& 


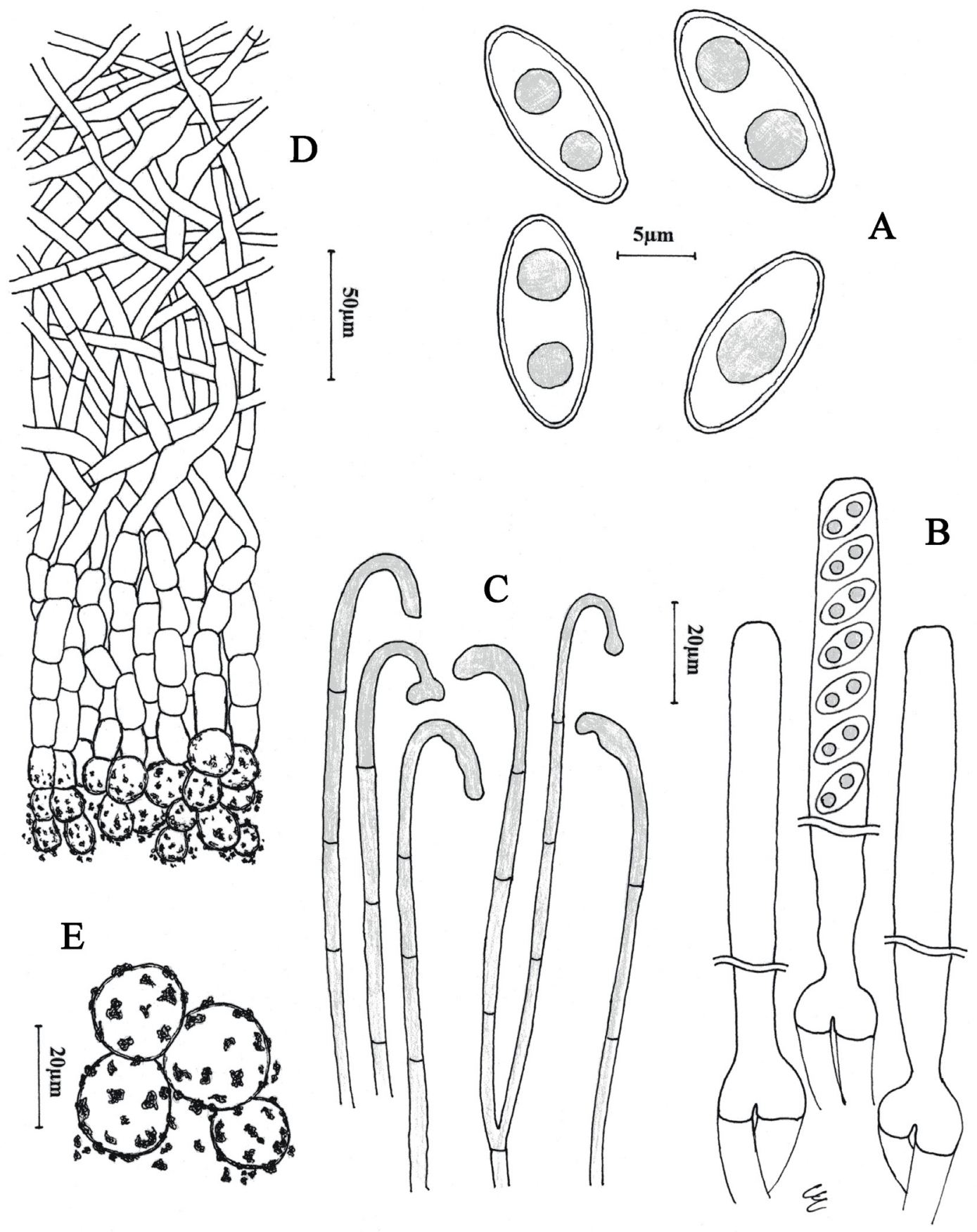

Fig. 3. Otidea mirabilis (Campo \& Vauras $25090 \mathrm{~F}$ ). $\mathrm{A}=$ spores, $\mathrm{B}=$ asci, $\mathrm{C}=$ paraphyses, $\mathrm{D}=$ medullary excipulum, $\mathrm{E}=$ ectal excipulum and external cells (magnified). 


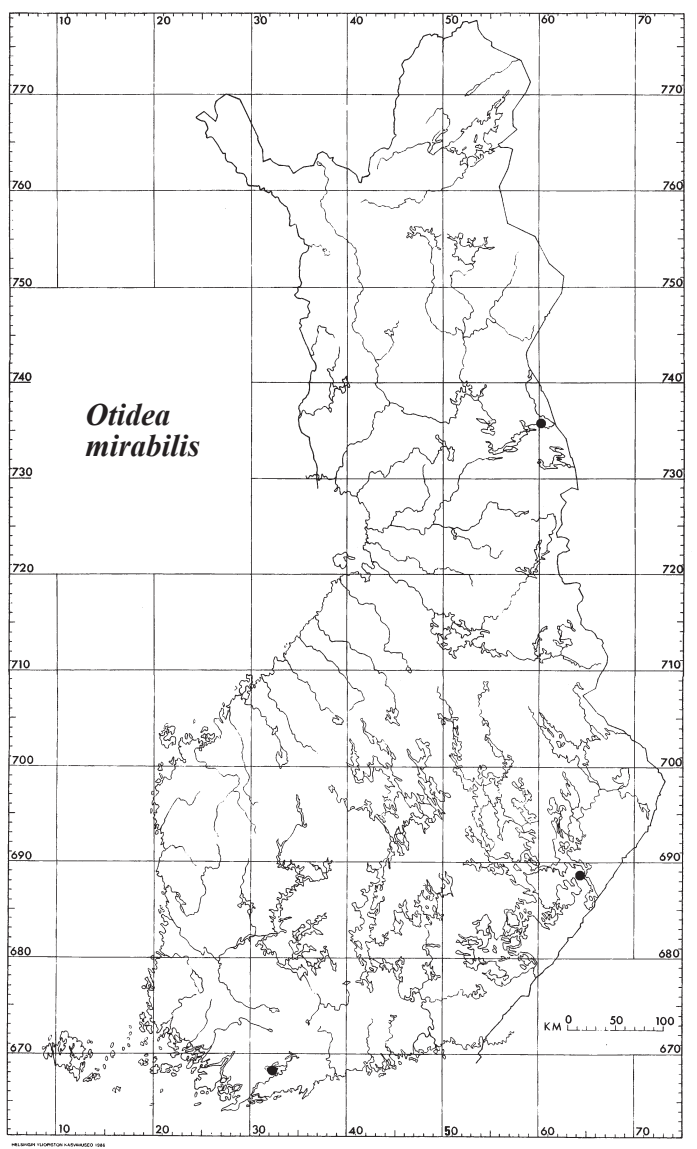

Fig. 4. Distribution of Otidea mirabilis in Finland according to the specimens examined.

Vauras and Tricholoma sulphurescens Bres. The third collection, the one from Kitee commune, comes from a man-made site with rich soil and abundant decaying wood.

\section{Discussion}

Otidea mirabilis was originally described from western Italian Alps (Jamoni 2001a, 2001b). In the summer 2007, during an excursion in Oulanka National Park, we collected ca. ten fruit bodies of this species. Our field determination was confirmed by the observation of microscopic characters. The comparison of the Finnish collection with the original material has revealed only a small, not significant difference in spore size range: $(13-) 13.5-15(-15.5) \times 6-7(-7.5) \mu \mathrm{m}$
(Nordic collection) vs. $12.5-14.5 \times 5.8-7 \mu \mathrm{m}$ (holotype, our measurements), 10-14.7(-15.5) $\times$ 6.4-7.2(-7.7) $\mu \mathrm{m}$ (according to the protologue). The particular colours (easily visible with the naked eyes) and the very few records convinced us that $O$. mirabilis is to be regarded as a very rare species. During the final revision of this article Van Vooren (2010) reported the presence of $O$. mirabilis from France, and he stated that the cited French collections (Mornand \& Courtecuisse 2005) are indeed $O$. mirabilis.

O. mirabilis is mainly characterized by the blue-violet colour of the external surface and the light ochraceous-yellow hymenium with a slight tinge of olive green, ear shaped apothecia and, microscopically, by the subfusoid spores and the lack of incrusted pigment in the hyphae of the medullary excipulum.In literature, we find other Otidea species with \pm bluish-purplish or purple colours on outer surface (see below), but they all lose (as $O$. mirabilis) this colour in exsiccata.

\section{Similar species}

Otidea bufonia (Pers.) Boud. [= Otidea umbri$n a$ (Pers.) Bres. = Otidea grandis (Pers.) Boud. sensu Vidal (1993, i.e. purplish coloured form)] and $O$. grandis f. maritima Jamoni ad interim (= Otidea bufonia f. fide Carbone \& Van Vooren, in prep.) belong to a variously interpreted species complex. Probably this complex is the most similar to $O$. mirabilis due to the presence of a blue-violet tint on the external surface, fading to rusty brown during the growth and the drying. The main differences that we found in $O$. bufonia (in all its range of colours) are: bigger and different shaped apothecia; apex of paraphyses without notches; a unique medullary excipulum with a typical kind of brown incrusting pigment in the hyphae (Korf \& Zhuang 1991).

Otidea caeruleopruinosa Harmaja seems to differ in many respects, first of all in spore size, even if many other features overlap quite well (for a comparison see Harmaja 2009). Otidea smithii Kanouse, described from North America, differs mainly in vinaceous colours and different spore shape. According to Kanouse (1950) and Tylutki (1993), the spores are not subfusoid. Otidea purpurea (M. Zang) Korf \& W.Y. Zhuang and Otidea subpurpurea W.Y. Zhuang, both described from China, are surely similar in colours but differ in clearly smaller spore size, being 
$8.7-10 \times 4.5-5 \mu \mathrm{m}$ in the former, and 10-11.5 $\times 5-6.5 \mu \mathrm{m}$ in the latter (Zang 1979, Zhuang \& Yang 2007).

Otidea lilacina R. Heim \& L. Remy, described from the French Alps, is a doubtful species, at least according to the original description, where we find microscopic features not fitting well with those of the genus Otidea (Heim \& Remy 1932). A re-examination of the type specimen is required to determine the right position of this taxon and its real identity, but this specimen seems to be lost (Van Vooren, pers. comm.). Finally, we must mention Otidea violacea A.L. Sm. \& Ramsb., which, although treated in the genus Otidea by Ellis \& Ellis (1988), surely belongs to the genus Peziza, according to the amyloid asci reported in the protologue (Smith \& Ramsbottom, 1916) and an unpublished type study made by Nannfedlt in 1932 (Van Vooren, pers. comm.).

\section{Otidea tuomikoskii Harmaja}

- Figs. 2, 5, 6

Otidea tuomikoskii Harmaja, Karstenia 15: 30. 1976.

\section{Original diagnosis}

Apothecia scissa, ad lateram oppositam elongata, extus brunneola et minutissime echinulata; hymenio flavido. Paraphyses uncinati, leniter incrassati et cum nonnullis gibbis ad apicem. Sporae oblongo-ellipsoideae, 9.0-11.0 × 5.0-5.7 um. - Typus: Finland, prov. Etelä-Häme, par. Lammi, Pappilankylä, Koiransuolenoja, in needles of Picea abies in ant hill, 1972-09-01, Risto Tuomikoski (H).

\section{Macroscopical features}

Fresh apothecia up to $6 \mathrm{~cm}$ long, narrowly earshaped, with pointed to more or less truncated apex, split on a side down to the base; short stipe covered by a white mycelium. Hymenium smooth, yellow, rarely whitish with yellow tints. External surface vertically corrugated, light yellow-orangish, covered by small warts, light orangish to brownish, usually darker than the background. In dry state up to $4 \mathrm{~cm}$ long and up to $2.1 \mathrm{~cm}$ wide, narrowly ear-shaped, with pointed to more or less truncated apex, lateral split running down to the base, short stipe cov- ered by a whitish mycelium. Hymenium smooth, light ochraceous yellow to somewhat darker in some specimens. External surface vertically corrugated, light orangish brown, entirely covered by conical-pyramidal warts, which appear darker than the background.

\section{Microscopic features}

Asci operculate, cylindrical, eight-spored, inamyloid, pleurorhynchous, $110-165 \times 8.5-10$ $\mu \mathrm{m}$. Paraphyses cylindrical, 2-2.5 $\mu \mathrm{m}$ wide, septate, branched below, bent apex slightly enlarged up to 3.5-4 $\mu \mathrm{m}$, with small notches on the concave side. Spores uniseriate, elliptical, smooth, hyaline, with two oil drops, (9-)9.5-11(-11.5) $\times$ 5.5-6(-6.5) $\mu \mathrm{m}, \mathrm{Q}=1.65-1.8$. Subhymenium a thick textura intricata made up of hyphae more or less perpendicular to the asci. Pale yellow when observed at low magnification. Medullary excipulum a textura intricata made up of cylindrical, septate hyphae up to 8 (10) $\mu \mathrm{m}$ wide. Sometimes a golden yellow crystalline incrusting pigment is present. Ectal excipulum a textura subglobulosa-angularis with elements up to 45 $\mu \mathrm{m}$ wide and/or long; external layer composed by chains of globose to ellipsoid, heavily incrusted elements. The chains are gathered in conicpyramidal heaps. Incrusting pigment brownish orange to amber coloured.

\section{Ecology, distribution and phenology}

Otidea tuomikoskii is a fairly exacting species most often growing in adult forests dominated by Picea abies. Its distribution (Fig. 6) shows clearly the preference to grow in eutrophic, lime-rich areas. Very often it is found growing amongst decaying needles of Picea abies, also often on old ant hills, and sometimes on decaying wood. The distribution of $O$. tuomikoskii ranges from the northern part of the hemiboreal zone to the southern part of the northern boreal zone. The Finnish collections of $O$. tuomikoskii date from Mid-August to early October. Most of them date from September. 


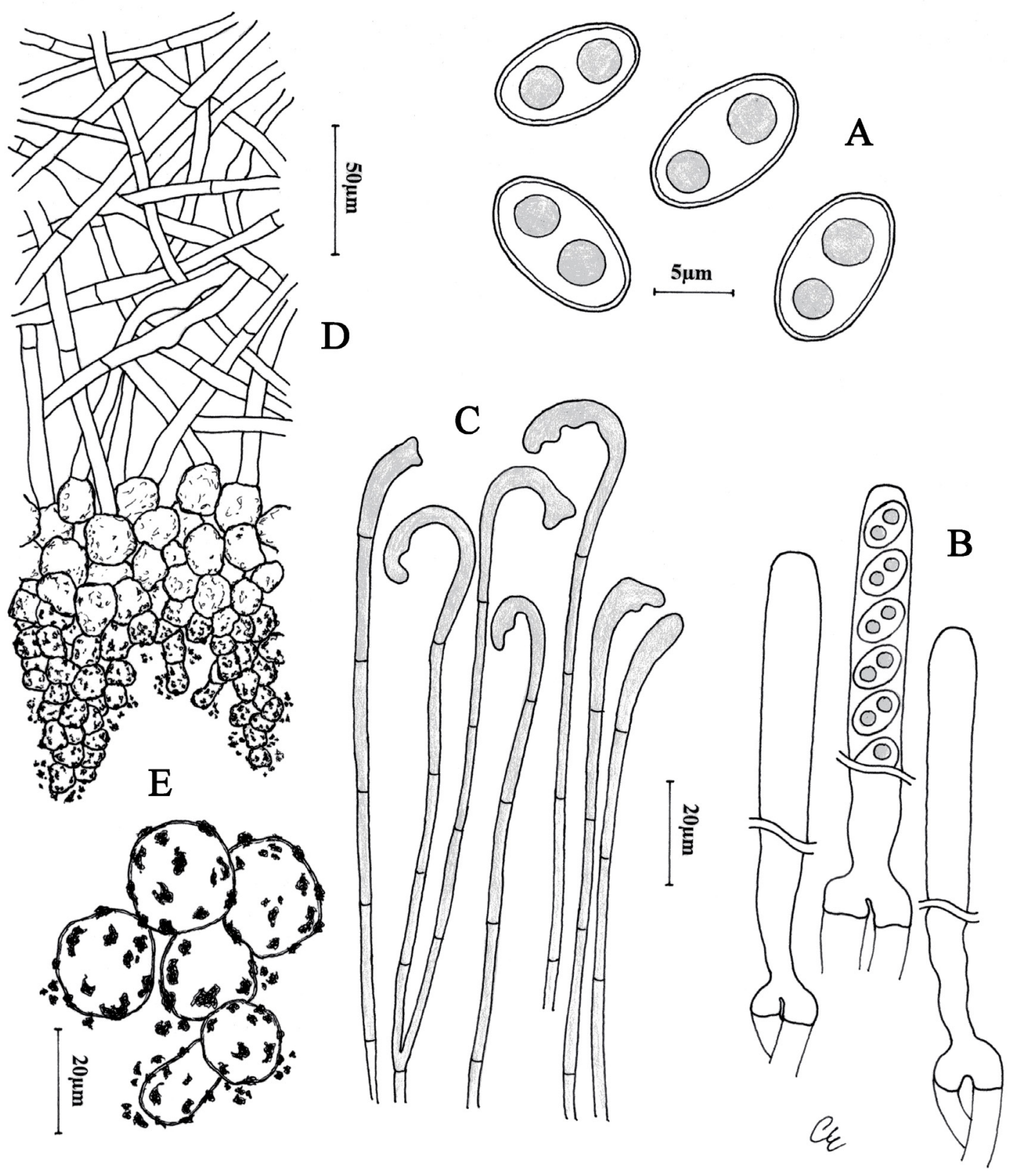

Fig. 5. Otidea tuomikoskii (Heinonen \& Heinonen 406-04F). A = spores, $\mathrm{B}=$ asci, $\mathrm{C}=$ paraphyses, $\mathrm{D}=$ medullary excipulum, $\mathrm{E}=$ ectal excipulum and external cells (magnified). 


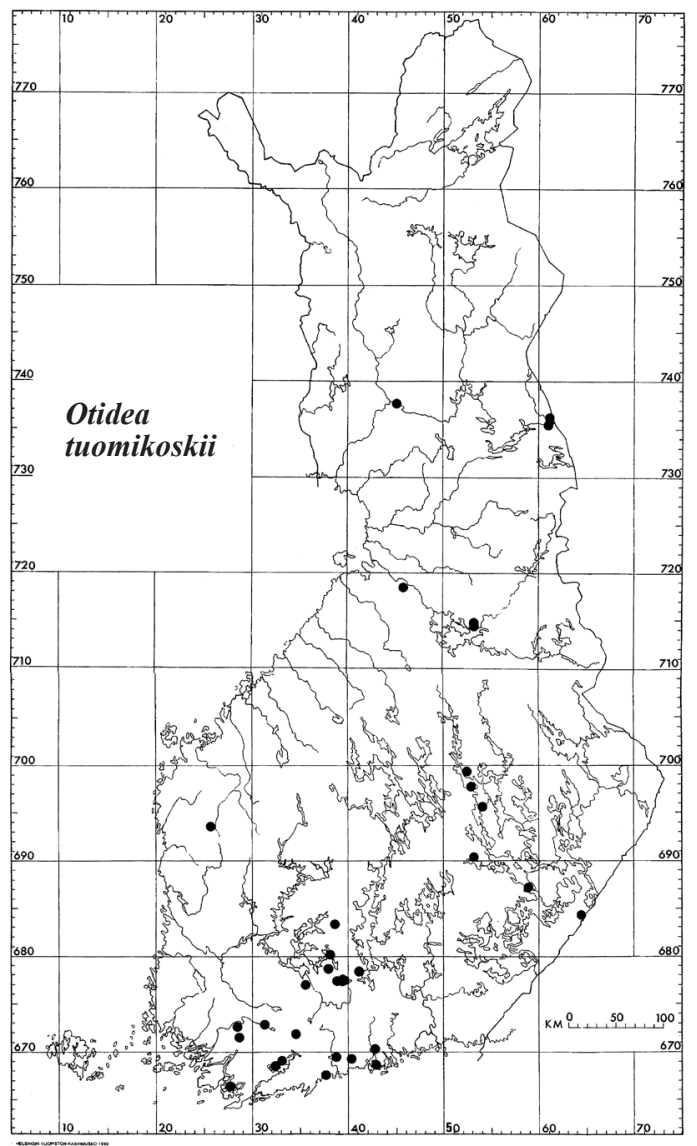

Fig. 6. Distribution of Otidea tuomikoskii in Finland according to the specimens examined.
Sarvala, 8.X.1967 Harmaja \& Nyyssönen (H). Hämeenlinna, Lammi, Halila, Reväsvuori SE, 4.IX.1971 Harmaja $(\mathrm{H})$, 5.IX.1988 Bondestam $(\mathrm{H})$; Hauhiala, Onnenvuori E, Lamminjärvi SSE, 6.IX.1973 Harmaja (H), 1.IX.1976 Harmaja (H), 7.IX.1976 Harmaja (H), 27.IX.1976 Harmaja (H), 6.X.1976 Harmaja (H), 19.VIII.1977 Harmaja (H), 8.IX.1977 Korhonen \& Tuomikoski $(\mathrm{H})$, 24.IX.1977 Heikkilä (KUO), 5.IX.1978 Harmaja (H, 2 collections), 29.VIII.1979 Korhonen \& Tuomikoski (H), 9.IX.1980 Harmaja (H), 7.IX.1988 Harmaja (H); Kilparisti, Mataramäki, 6.IX.1979 Leino (H); Pappilankylä, Koiransuolenoja, 23.IX.1977 Korhonen \& Tuomikoski (H); Tuulos, Juttila, Leheejärvi N, 6.IX.1981 Liukkonen (H). Pälkäne, Luopioinen, Kuohijoki, Kipparinlahti W, 12.IX.1997 Haikonen 18719 (H). Somero, Kultela, Suulinki. 17.IX.1967 Såltin (TUR). Etelä-Savo. Savonlinna, Hevonmaa, Lahnasenvuori, 17.IX.2003 Huhtinen (TUR), 19.IX.2004 Rahko (TUR). Laatokan Karjala. Parikkala, Saari, Saarenkylä, Kauramäki, 11.IX.2007 Vauras (TUR). Etelä-Pohjanmaa. Kauhajoki, Vanhakylä - Lustila, Ikkelänjoki S, 20.IX.2005 Ohenoja (H). Pohjois-Savo. Joroinen, Maavesi, Italiankylä, 12.IX.1980 Kytövuori 80943 (H). Kuopio, 1964-65 Hakala (TUR); Neulaniemi, 7.IX.1973 Savolainen \& Miettinen (KUO); Vehmersalmi, Puutosmäki, Pitkälahti, 12.IX.1981 Heikkilä (H), 30,VIII,1985 Höijer (H). Siilinjärvi, Väänälänranta, Paasimäki W, 19.IX.1974 Fagerstén (KUO). Kainuu. Paltamo, Melalahti, Myllymäki, 4.X.1976 Harmaja (H), 26.IX.1977 Harmaja (H); Melalahti, Salmenniemi, 15.VIII.1984 Väre \& Ohenoja (OULU); Melalahti, Viilonkallio, 10.IX.1986 Ulvinen (OULU). Oulun Pohjanmaa. Muhos, Suokylä, Liimanninkoski, 28.IX.1975 Ohenoja (OULU). Koillismaa. Kuusamo, Juuma, Jäkälävuoma-gorge, NE end, near Harrisuvanto, 27.VIII.1970 Harmaja (H), 25.VIII.1978 Harmaja (H), 25.VIII.1978 Ulvinen (OULU); Hautaniitynvuoma - Harrisuvanto the mouth of Jäkälävuoma, 5.IX.1981 Kytövuori 811199 (H); Liikasenvaara, Sirkkapuro, 22.VIII.1974 Ulvinen (OULU), 28.VIII.1979 Ulvinen (OULU), 18.VIII.1993 Ohenoja (OULU), 16.VIII.2009 Carbone \& Vauras $26954 F$ (TUR-A). Perä-Pohjanmaa. Rovaniemi, Koskenkylä E, 17.VIII.1974 Ulvinen (OULU).

\section{Discussion}

O. tuomikoskii was described by Harmaja (1976) with few, but well detailed and useful notes. The paper lacks any picture or drawing. O. tuomikoskii is poorly cited in mycological literature. In fact, it has only been reported from China (Cao et al. 1990) and from USA (Peterson, 1999), and lastly with a wider geographical range from Finland, Sweden, Czech Republic, France and Germany by Van Vooren et al. (2008), who gave good colour photographs and a revision of the type specimens.

The Chinese collections are described with slight differences in colours and apothecia size "exterior brown ("Sepia") to dull brown ("Amja (H). Hattula, Nihattula, Ilveskallio - Särkistenkallio, 19.VIII.1993 Kytövuori 93-353 (H). Kuhmoinen, Päijälä, 
ber brown") ... smaller than that of Finnish material $(1-2.5 \times 0.4-1 \mathrm{~cm}$ vs $2-4 \times 0.5-2.5 \mathrm{~cm}$ $=$ height $\times$ width)" (Cao et al. 1990). The first author examined a duplicate Chinese collection, cited by Cao et al. (1990) and deposited in Helsinki (H 7002017, dupl. MHSU 818). He found that, unfortunately, the specimen consists of tiny fragments not useful to ascertain the original shape and size of the apothecium. However, a very short stipe is present, confirming the small size of the apothecium as reported by the Chinese authors. The external surface is rough, but it seems to be slightly different from the typical warty one of the Finnish material. Spore size and paraphyses fit quite well with the ones of this species, but the ectal excipulum is not so typical. We think that it could be better (and useful) to study more and well preserved material before confirming the presence of $O$. tuomikoskii in China.

Peterson (1999) stated that this taxon had been misinterpreted under the name Otidea leporina var. minor by the "workers in the Pacific Northwest in USA". The only doubt about the American material could be spore size, (9.2-)10.4 10.6(-11.6) × (4.9-)6.6-6.7 (-6.7) $\mu \mathrm{m}$, being a little wider than European ones. According to Peterson (1999), we find that, although lacking micro-features, States (1990, p.182), SchalkwijkBarendsen (1991, p. 186) and Barron (1999, p.65), published under O. leporina some colour photographs and/or drawing definitely recalling Otidea tuomikoskii. Finally, Van Vooren et al. (2008) in their type study of Otidea tuomikoskii, found a little longer spore size, up to $12 \mu \mathrm{m}$ in length and up to $6,5 \mu \mathrm{m}$ in width, and they gave a very detailed description of all the other microfeatures. Otidea tuomikoskii must be regarded as a good species characterized by unique features, visible also in dry specimens owing to the narrowly "otideoid" shape, the yellowish hymenium and the warty external surface with conical-pyramidal warts.

The studied collections reveal a connection between $O$. tuomikoskii and Picea abies. This connection ("In litter: mainly spruce needles") is also supported by Harmaja (2009). He also stated that the species "may somewhat prefer old-growth forest" and "somewhat prefers nutrient-rich soils (has even been encountered on truly calcareous ground)". Our own collection (16.VIII.2009) from Kuusamo, Oulanka National Park, "Sirkka- puro" (nowadays in the maps Uopajanpuro), fits well to the last description by Harmaja. The species had already been collected there in 1974 by R. Tuomikoski (Harmaja 1976). We found more than a hundred fruit bodies in a rich brookside forest, at two fallen, old trees of Picea abies. The site was characterized by the vascular plants Ribes spicatum, Circaea alpina, Equisetum pratense and Gymnocarpium dryopteris.

\section{Similar species}

Otidea nannfeldtii Harmaja is a poorly known species due to the lack of further studies and pictures. This species is said to be very similar to $O$. tuomikoskii, from which it differs mainly in the subglabrous external surface ("even under the lens"), and for the wider and shorter spores, being 9-10 × 5.4-6.4 $\mu \mathrm{m}$, and also for the apex of the paraphyses, which are up to $5 \mu \mathrm{m}$ wide (Harmaja 1976).

Otidea papillata Harmaja var. papillata and Otidea papillata f. pallidefurfuracea Van Vooren \& Hairaud are close, but differ in the warty external surface, made up of large, dark (or whitish in f. pallidefurfuracea) pustules contrasting with background, and for the different alutaceous colours (also in dry specimens), giving it a close appearance of Otidea alutacea (Pers.) Massee. Van Vooren et al. (2008) maintained that it differs from $O$. alutacea in the warty external surface and in the spores being smaller and not "cylindical". These features should also separate it from Otidea microspora (Kanouse) Harmaja, which is supposed to be a "small spored $O$. alutacea". Otidea angusta Harmaja is described as a species close to $O$. nannfeldltii and O. tuomikoskii, from which it seems to differ in many features (Harmaja 2009). A note on the small spored taxon Otidea onotica var. brevispora Zhuang is published by Carbone (2009).

Otidea formicarum Harmaja is another small spored taxon, and described as follow: apothecia truncate, yellow ochraceous on both hymenium and external surface (dry state), paraphyses with bent apex, enlarged up to $5 \mu \mathrm{m}$, spores narrowly ellipsoid to oblong, $8.5-10 \times 5.2-6.2 \mu \mathrm{m}$; growth on ant hills (Harmaja 1976). Unfortunately nothing is said about the excipular morphology. Also the habitat is not "exclusive" being reported also for O. tuomikoskii (Harmaja 2009). During the revision of the Otidea sp. deposited in TUR, the 
first author found a good slide of this species that will be published in a separate paper. As far as we know the only colour picture of this taxon is published in Salo et al. (2006).

Otidea sinensis J.Z. Cao \& L. Fan from China is supposed to be close to O. tuomikoskii, in fact the Chinese authors put them in dichotomy in their key. O. sinensis is said to differ mainly for the fusoid spore shape (Cao et al. 1990).

Acknowledgements: Our thanks are due to the curators of the herbaria $\mathrm{H}$ and OULU for arranging the loans. Further, we sincerely thank Maija-Liisa and Pekka Heinonen for their great work in collecting and depositing specimens in TUR; Pier Giovanni Jamoni and Daniele Bolognini for the quick loan of the type collection of $O$. mirabilis; and Nicolas Van Vooren for critical revision of this paper, and Ernest and Valerie Emmett for useful comments and for checking the English.

\section{References}

Barron, G. 1999: Mushrooms of Northeast North America. -336 pp. Lone Pine Publishing, Edmonton.

Cao, J.-Z., Fan, L. \& Liu, B. 1990: Some species of Otidea from China. - Mycologia 82 (6): 734-741.

Carbone, M. 2009: Il genere Otidea. I. Sull'identità di Peziza onotica. - Rivista di Micologia 52: 11-28.

Ellis, M.B. \& Ellis, J.P. 1988: Microfungi on Miscellaneous Substrates. An Identification Handbook. - 244 pp. Croom Helm, London \& Sydney.

Harmaja, H. 1976: New species and combinations in the genera Gyromitra, Helvella and Otidea. - Karstenia 15: 29-32.

Harmaja, H. 2009: Studies in Otidea (Pezizales). Karstenia 48: 33-48.

Heim, R. \& Rémy, L. 1932: Fungi Brigantiani (troisième série) : espèces rares ou nouvelles de Discomycètes des Alpes briançonnaises. - Bull. Soc. mycol. Fr. 48: 53-75.

Jamoni, P.G. 2001a: Validazione di nuovi taxa. - Funghi e Ambiente 56: 85-86.

Jamoni, P.G. 2001b: Reperti rari e nuovi della zona montana e subalpina della Valsesia. - Fungi non delineati XIV: $1-60$.

Jamoni, P.G. 2003: Appunti dul genere Otidea (Pers.) Bonorden. - Funghi e Ambiente 93: 23-39.

Kanouse, B.B. 1950: Studies in the genus Otidea. - Mycologia 40: 482-504.

Korf, R.P. \& Zhuang, W.-Y. 1985: Some new species and new records of discomycetes in China. - Mycotaxon 22: 483-514.

Korf, R.P. \& Zhuang, W.-Y. 1991: A preliminary discomycete flora of Macaronesia: part 15, Terfeziaceae, and Otideaceae, Otideoideae. - Mycotaxon 40: 413433.

Mornand, J. \& Courtecuisse, R. 2005: Le genre Otidea et espèces affines en France. - Bull. mens. Soc. linn. Lyon 74: 65-84.
Peterson, E.T. 1999: Systematics of the genus Otidea in the Pacific Northwest. - Master thesis of the Oregon State University, 149 pp.

Salo, P., Niemelä, T. \& Salo, U. 2006: Suomen sieniopas. -512 pp. Kasvimuseo \& WSOY, Helsinki.

Schalkwijk-Barendsen, H.M.E. 1991: Mushrooms of Western Canada. - 414 pp. Lone Pine Publishing, Edmonton.

Smith, A.L. \& Ramsbottom, J. 1916: New or rare microfungi. - Trans. Brit. Mycol. Soc. 5: 231-248.

States, J.S. 1990: Mushrooms and truffles of the Southwest. - 232 pp. University of Arizona Press.

Tylutki, E.E. 1993: Mushrooms of Idaho and the Pacific Northwest. Vol. 1. Discomycetes. - 133 pp. University of Idaho Press, Moscow.

Van Vooren, N. 2010: Note sur Otidea mirabilis (Pezizales). - Ascomycete.org 2: 33-35.

Van Vooren, N., Hairaud, M. \& Jindřich, O. 2008: Otidea tuomikoskii, Otidea papillata et Otidea papillata f. pallidefurfuracea f. nov., trois taxons remarquables appartenant au genre Otidea (Pezizales, Pyronemataceae). - Bull. Mycol. Bot. Dauphiné-Savoie 48 (188): 47-57.

Vidal, J.M. 1993: Bolets de Catalunya 12: 587.

Zang, M. 1979: Some new species of higher fungi from Xizang (Tibet) of China. - Acta Bot. Yunnanica 1: 101-104.

Zhuang, W.-Y. \& Yang, Z.-1. 2007: Some Pezizalean Fungi from Alpine Areas of Southwestern China. - Mycol. Montenegrina 10: 235-249. 

